\title{
APLIKASI CYBER COUNSELING DENGAN MENGOPTIMALKAN WHATSAPP BERBASIS KOMPUTASI MOBILE
}

\author{
Alexius Endy Budianto ${ }^{1)}$, Nur Hidayah ${ }^{2)}$, Abdul Aziz ${ }^{3)}$ \\ ${ }^{1)}$ Department of Informatic, Kanjuruhan University Malang \\ ${ }^{2)}$ Department of Education, Universitas Negeri Malang \\ 3) Department of Informatic, Kanjuruhan University Malang \\ email : endybudianto@unikama.ac.id ${ }^{1)}$,nur.hidayah.fip@um.ac.id ${ }^{2)}$,aziz.bangle@gmail.com ${ }^{3)}$
}

\begin{abstract}
Abstrak
Penelitian jangka panjang ini bertujuan untuk memudahkan guru dalam menggambarkan satu model layanan konseling. Guru dituntut untuk dapat memberikan layanan yang baik dan terbaik melalui proses bimbingan konseling. Perkembangan Teknologi Informasi dan Komunikasi (TIK) dapat dimanfaatkan dalam konseling cyber dan penanganan berbagai layanan, misalnya, hampir semua siswa memiliki ponsel yang rata-rata sudah dapat dimanfaatkan untuk membangun sistem dengan mengoptimalkan komputasi mobile berbasis Whatsapp yang mampu menyediakan layanan konseling elektronik dan menghemat waktu dan biaya.

Bimbingan dan konseling layanan tidak selalu bertatap muka. Ada layanan yang lebih mudah yaitu dengan konseling cyber yang memungkinkan konseling tidak merasa malu atau canggung yang dapat dilakukan kapan saja dan di mana saja. Pemanfaatan Teknologi Informasi dan Komunikasi (TIK) pada zaman kontemporer menjadi sangat relevan ketika diterapkan dalam kegiatan bimbingan dan konseling. Oleh karena itu, diharapkan juga meningkatkan peneliti baik keterampilan dan kompetensi yang akan mendorong lembaga tempat peneliti bekerja, yaitu: Universitas Kanjuruhan Malang.
\end{abstract}

Kata Kunci:

E-Counseling, Cyber Counseling, Whatsapp, Mobile Computing

\begin{abstract}
This long-term study aims to make it easier for teachers to describe one model of counseling services. Teachers are required to be able to provide good and best service through the process of counseling guidance.The development of Information and Communication Technology (ICT) can be utilized in cyber counseling and handling of various services, for example, almost all students have mobile phones which on average can already be utilized to build the system by optimizing whatsapp based mobile computing capable of providing $e$ counseling services and saving time and cost.

Service Guidance and counseling is not always face to face. There is an easier service that is with cyber counseling that allows counseling not feel embarrassed or awkward that can be done anytime and anywhere. Utilization of Information and Communication Technology (ICT) in contemporary times become very relevant when applied in guidance and counseling activities. Therefore, it is expected to also increase the researcher both skill and competence that will boost the institution where the researchers work, namely: Kanjuruhan University Malang.
\end{abstract}

Keywords :

E-Counseling, Cyber Counseling, Whatsapp, Mobile Computing

\section{PENDAHULUAN}

Dalam penelitian ini bertujuan untuk membantu bimbingan dan konseling guru (BK) agar dapat melaksanakan tugas dan tanggung jawabnya secara optimal. Bimbingan konseling baik di sekolah maupun di luar sekolah diperlukan untuk memiliki wawasan, pengetahuan, keterampilan dan nilai-nilai dan sikap dalam mencapai tujuan layanan konseling. Dampak 
pada pemecahan masalah harus diorientasikan kembali. Kita tidak lagi harus berpikir tentang bagaimana menyelesaikan masalah (problem solving), tetapi bagaimana mengenali potensi dan mengantisipasi masalah dengan potensi ini. Ini terus menerus dengan reorientasi bimbingan dan konseling saat ini (BK). Bahwa konsentrasi BK saat ini bukan pada masalah siswa yang harus diselesaikan, tetapi bagaimana mengenali potensi dan menggunakan strategi preventif-perkembangan untuk membantu siswa mewujudkan potensi mereka [25] Tidak mengherankan bahwa disiplin konseling telah dipengaruhi oleh perkembangan teknologi. Semakin banyak teknologi meningkat, semakin banyak profesional yang membantu perlu memanfaatkan teknologi baru. Internet adalah teknologi baru yang memengaruhi bidang psikologi konseling. [4] Seiring dengan ledakan dunia cyber untuk koneksi, pembelajaran dan hiburan, ada pertumbuhan yang sangat cepat dalam permintaan individu-individu dari segala usia untuk dunia konseling atau e-terapi [9]. Konseling dunia maya atau e-Terapi dianggap sebagai cara realistis untuk menanggapi permintaan layanan kesehatan mental, permintaan yang diperkirakan akan meningkat secara eksponensial di tahun-tahun mendatang. [3] Selain itu, fasilitas dan infrastruktur juga diperlukan, misalnya ketersediaan ruang konseling, buku, media visual (rekaman konseling) dan program aplikasi instrumen yang digunakan untuk membantu bimbingan konseling di sekolah sebagai model yang menggambarkan layanan konseling yaitu -Konseling dan memanfaatkan Teknologi Informasi di BK. Karena itu sangat penting untuk mempersiapkan siswa bagi pekerja sosial untuk memanfaatkan teknologi yang kompeten dalam praktik mereka. [8] Menurut Statsky (2016: 565) mengatakan bahwa "Smartphone adalah ponsel yang melakukan banyak fungsi komputer yang dioperasikan oleh perangkat layar sentuh [23]. Itu adalah smartphone (ponsel pintar) yang merupakan ponsel yang banyak fungsi dari komputer, perangkat beroperasi dengan layar sentuh ". [22] Dalam penelitian ini kami akan mengoptimalkan whatsapp berdasarkan komputasi seluler karena hampir semua siswa sekolah menengah kejuruan memiliki ponsel, sehingga guru dapat melakukan layanan bimbingan dan konseling seperti itu tidak selalu bertatap muka atau bertatap muka. Ada layanan yang lebih mudah, yaitu konseling cyber yang memungkinkan konseling tidak merasa malu atau canggung yang dapat dilakukan kapan saja dan di mana saja. Penggunaan Teknologi Informasi dan Komunikasi (TIK) di masa kontemporer sangat relevan ketika diterapkan dalam kegiatan bimbingan dan konseling. Studi terbaru menunjukkan bahwa instant messenger paling populer adalah WhatsApp. [24] Oleh karena itu, ini diharapkan efektif untuk membantu guru dan individu secara optimal mengembangkan dan beradaptasi dengan kemajuan zaman tanpa terkikis oleh pengaruh negatif. 


\section{TINJAUAN PUSTAKA}

\subsection{Definisi Teknologi Informasi dan Komunikasi (TIK)}

Menurut Fitrihana (2007), TIK adalah suatu sistem atau teknologi yang dapat mengurangi batasan ruang dan waktu untuk mengambil, memindahkan, menganalisis, menyajikan, menyimpan dan menyampaikan informasi data menjadi informasi. [12] Dan dalam konteks pembelajaran, TIK mencakup semua hal yang terkait dengan penggunaan komputer untuk memproses informasi dan sebagai alat bantu belajar serta sumber informasi untuk guru dan siswa.

\subsection{Memahami Cyber Counseling}

a. Cyber Counseling

Moh. Surya (2006) mengemukakan bahwa sejalan dengan perkembangan teknologi komputer, interaksi antara konselor dan klien tidak hanya dilakukan melalui hubungan tatap muka tetapi juga dapat dilakukan melalui hubungan virtual (virtual) melalui internet dalam bentuk "konseling cyber". Layanan bimbingan dan konseling ini adalah salah satu model layanan konseling inovatif dalam upaya menunjukkan layanan praktis dan dapat dilakukan di mana saja selama ada koneksi atau terhubung ke internet. [13]

Konseling Cyber adalah strategi atau konseling virtual dan konseling yang dilakukan melalui bantuan koneksi internet. Dalam hal ini proses konseling berlangsung melalui internet dalam bentuk situs web, email, facebook, konferensi video (Yahoo massangger) dan ide-ide inovatif lainnya. Proses konseling menggunakan konseling cyber atau konseling virtual berarti bahwa konselor dan klien tidak hadir secara fisik dalam waktu dan ruang yang sama. [25]

b. Konsep Cyber Counseling

Kata siber adalah istilah dari internet. Istilah internet tentu tidak asing lagi di telinga kita, karena sejak kemunculannya pada tahun 1969 dan mengalami perkembangan yang sangat pesat pada tahun 1993/1994, kehadiran internet telah membawa perubahan signifikan pada berbagai perubahan dalam aspek kehidupan manusia, terutama dalam hal kebebasan untuk mendapatkan dan menyebarkan informasi tanpa mengetahui batas geografis. Saat ini ada tiga pendapat yang mengatakan bahwa internet adalah singkatan dari International Network, Internetworking, dan Interconnected Network. Tetapi beberapa ahli cenderung menyebutnya saling berhubungan. Internet yang lebih dalam adalah kumpulan jaringan komputer dunia yang terdiri dari jutaan unit kecil, seperti jaringan pendidikan, jaringan 
bisnis, jaringan pemerintah, dll., Yang bersama-sama menyediakan layanan informasi seperti email, obrolan online, transfer file, dan saling merawat.

Bentuk layanan bimbingan dan konseling yang dapat dicari adalah layanan konsultasi, layanan informasi, layanan konseling individu, layanan konseling kelompok, dan layanan lain yang dapat dikembangkan oleh masing-masing konselor dan sesuai dengan kebutuhan konseling.

\subsection{Aplikasi Smartphone berbasis Android}

Memahami Aplikasi Smartphone Berdasarkan Android Aplikasi berasal dari aplikasi kata yang berarti aplikasi, aplikasi, penggunaan. Memahami aplikasi adalah program yang siap digunakan yang dapat digunakan untuk menjalankan perintah pengguna dengan tujuan mendapatkan hasil yang lebih akurat sesuai dengan tujuan pembuatan aplikasi. [20] Untuk dapat menggunakan aplikasi Android, pengguna harus mengunduh dan menginstal file terlebih dahulu dengan ekstensi .apk, fasilitas ini dapat diakses melalui aplikasi bernama Play Store yang tersedia di setiap ponsel Android. [19]

\subsection{Whatsapp}

Whatsapp adalah aplikasi pengiriman pesan instan yang memungkinkan kita mengirim file, pesan, gambar, video, foto, dan obrolan online seperti Blackberry Massenger. Tapi WhatsApp lebih menarik bagi pengguna iPhone, seperti apa yang pertama kali muncul WhatsApp untuk iPhone Apple. Seiring dengan perkembangan whatsapp, sekarang aplikasi ini tersedia untuk versi Android, Windows Phone Blackbarry dan Symbian. Whatsapp, juga merupakan salah satu aplikasi terlaris yang diunduh di seluruh dunia, terutama untuk pengguna Smartphone. $[5,18,16]$

Aplikasi Whatsapp tidak memerlukan pulsa seperti SMS untuk beroperasi, karena hanya membutuhkan paket data internet (EDGE / 3D) atau wifi. Pengguna kontak Whatsapp dapat secara otomatis terdeteksi pada perangkat ponsel cerdas kami jika ponsel kami juga menggunakan aplikasi whatsapp. Saat ini Whatsapp sangat populer untuk pengguna Smartphoen Android, Blackberry, Iphone, Ipad, Tablet, dan juga ponsel Windows. Whatsapp dapat diunduh secara gratis di Google Play Store (Android), Blackberry App World, Nokia OVI Store, Windows Phone Marketplace, Iphone App Store atau di situs web resmi Whatsapp. 
URL : https://jurnal.machung.ac.id/index.php/kurawal

\subsection{Mobile Computing}

Pengertian komputasi mobile adalah kemampuan teknologi untuk menghadapi pergerakan / pergerakan manusia dalam penggunaan praktis komputer. Beberapa konsep komputasi bergerak meliputi: $[1,11,14]$

\section{METODE PENELITIAN}

Metode yang digunakan dalam penelitian ini adalah metode deskriptif, yang bertujuan untuk memperoleh gambaran umum tentang objek penelitian. Dengan metode ini bertujuan untuk mendapatkan karakteristik, keadaan, gejala yang tepat dari suatu kelompok [15]. Dengan metode ini diharapkan dapat memperoleh gambaran respon siswa terhadap implementasi layanan konseling siswa dengan mengoptimalkan whatsapp (WA) di Sekolah Menengah Kejuruan (SMK) di Kabupaten Malang.

Populasi yang digunakan dalam penelitian ini adalah semua siswa SMA / SMK di Kota Malang yang berjumlah 28.696 siswa. Dari jumlah ini kita ambil contohnya SMK Brantas Karang Kates Jl. Lolaras 14 Karangkates Sumberpucung dengan jumlah siswa 650, populasinya cukup besar karena di atas 500 siswa, maka peneliti mengambil $50 \%$ populasi untuk dijadikan sampel. Sampel yang digunakan dalam penelitian ini ditentukan dengan randem sampling. Dengan mengambil angka ganjil dalam urutan total populasi. Setelah data sampel randem diperoleh, dapat dilihat pada tabel 1.

Alat pengumpulan data yang digunakan adalah kuesioner tentang respons siswa terhadap penerapan bimbingan konseling pribadi di setiap departemen yang terdiri dari dua pilihan (ya / tidak). Untuk menentukan hasil tanggapan siswa terhadap penerapan bimbingan konseling pribadi. Kemudian gunakan analisis statistik dengan teknik presentasi dapat dilihat di Tabel 2.

Tabel 1 Layanan Konseling dengan mengoptimalkan whatsapp (WA)

\begin{tabular}{llccccccc}
\hline No & \multicolumn{2}{c}{ DEPARTMENT } & 11 CLASS & \multicolumn{2}{c}{12 CLASS } & \multicolumn{2}{c}{ TOTAL } & DISCRIPTION | \\
\hline & & POP & SAM & POP & SAM & POP & SAM & \\
1 & Automotif & 36 & 23 & 36 & 23 & 62 & 36 & \\
2 & TKR & 38 & 29 & 37 & 28 & 85 & 47 & \\
3 & RPL & 39 & 25 & 38 & 29 & 77 & 44 & $\mathrm{~Pa} / \mathrm{Pi}$ \\
4 & Multimedia & 32 & 21 & 22 & 21 & 54 & 32 & \\
5 & TKJ & 33 & 16 & 21 & 10 & 64 & 26 & \\
\hline & TOTAL & 178 & 144 & 154 & 111 & 342 & 185 & \\
\hline
\end{tabular}

Sumber: Data olahan 2017 
URL : https://jurnal.machung.ac.id/index.php/kurawal

Tabel 2 Analisis Statistik dengan Teknik Presentasi

\begin{tabular}{lll}
\hline NO & PERCENTAGE & DISCRIPTION \\
\hline 1 & $81-100$ & VERYWELL \\
2 & $61-80$ & WELL \\
3 & $41-60$ & ENOUGHGOOD \\
4 & $21-40$ & LESS \\
5 & $0-20$ & LESS GOOD \\
\hline
\end{tabular}

Untuk menemukan persentase item yang dipilih oleh siswa, peneliti menggunakan teknik persentase berikut:

$$
P=\frac{F}{N} \times 100 \%
$$

Deskripsi:

$$
\begin{aligned}
& \mathrm{P}=\text { Presentasi yang dicari } \\
& \mathrm{F}=\text { Frekuensi jawaban } \\
& \mathrm{N}=\text { Jumlah Sampel }
\end{aligned}
$$

\section{HASIL PENELITIAN}

Jika dilihat dari tanggapan siswa terhadap penerapan bimbingan konseling pribadi dengan mengoptimalkan whatsapp berdasarkan aspek yang diukur, hasilnya adalah sebagai berikut:

1. Tanggapan siswa terhadap penerapan bimbingan konseling pribadi dengan mengoptimalkan whatsapp dalam aspek penempatan di kelas berdasarkan kondisi fisik dan pribadi siswa mendapatkan persentase $(61,83 \%)$ yang diklasifikasikan dalam kategori baik. Ini membuktikan bahwa layanan bimbingan konseling pribadi siswa telah dilaksanakan dengan baik. Meski begitu masih ada beberapa yang belum terjangkau layanan, yaitu sebesar $(31,17 \%)$

2. Respon siswa terhadap penerapan penempatan dan distribusi dalam bimbingan konseling pribadi dengan mengoptimalkan whatsapp pada aspek penempatan dan distribusi keterampilan dan seni sesuai dengan bakat dan minat siswa, maka persentase yang diperoleh $(66,30 \%)$, yang termasuk dalam kedua kategori. Namun masih ada $(33,70 \%)$ siswa yang masih belum mendapatkan layanan. 
URL : https://jurnal.machung.ac.id/index.php/kurawal

3. Respon siswa terhadap layanan penempatan dan penyaluran dalam bimbingan konseling pribadi dengan mengoptimalkan whatsapp dalam aspek kegiatan ekstrakurikuler yang dapat digunakan sebagai kebiasaan sikap keagamaan, bakat dan minat. Respon yang diharapkan dari responden adalah $(62,36 \%)$, yang termasuk dalam kategori baik. Namun masih ada $(37,64 \%)$ yang masih belum mendapatkan layanan

4. Respons siswa terhadap aplikasi yang diuji untuk memenuhi kebutuhan bimbingan konseling pribadi dengan mengoptimalkan whatsapp agar lebih efektif dan efisien baik dari segi kebutuhan maupun kecepatan komunikasi bimbingan seperti yang ditunjukkan Gambar 1, 2, dan 3.

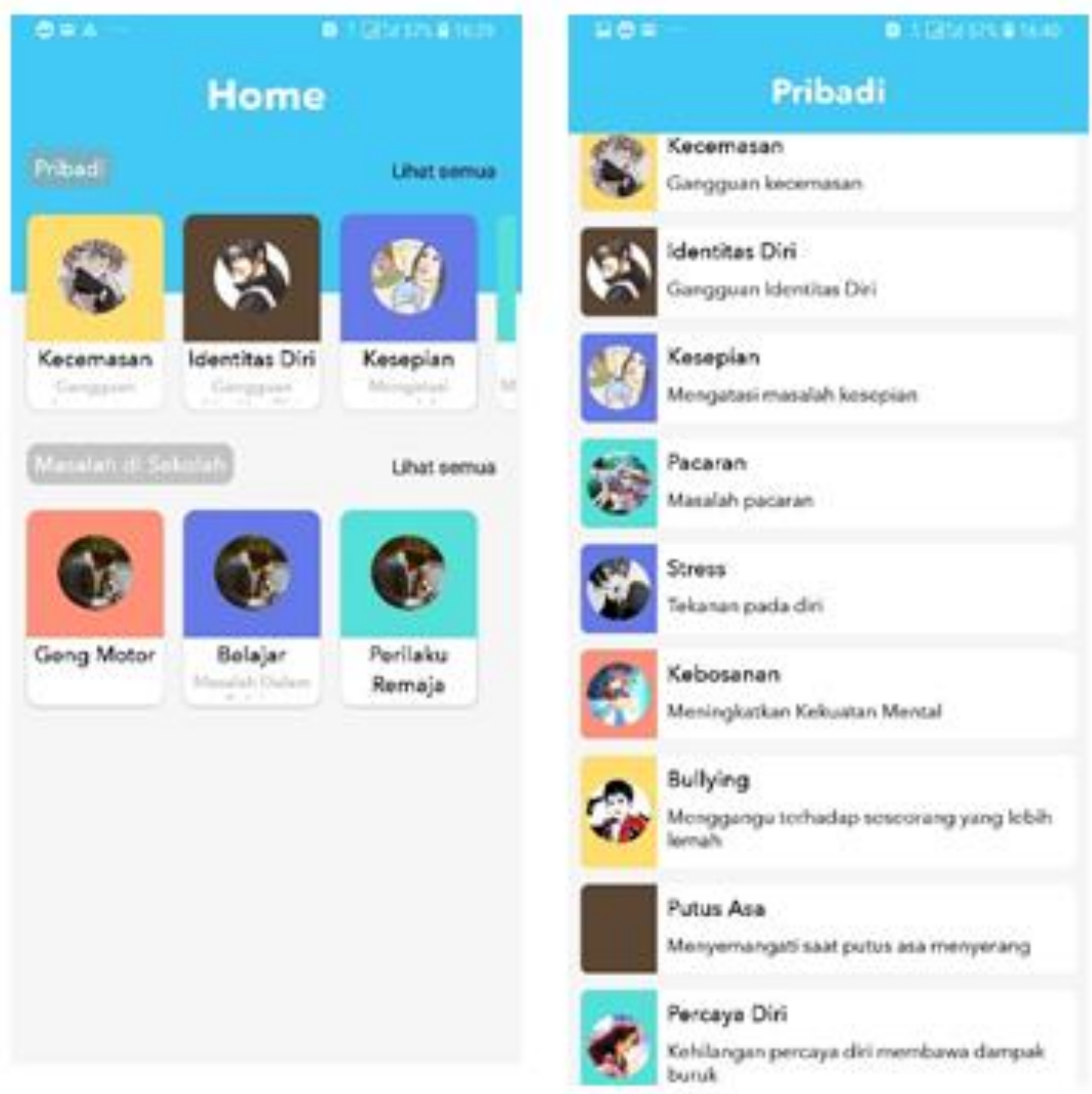

Gambar 1 Menu Utama Aplikasi Bimbingan Konseling 
URL : https://jurnal.machung.ac.id/index.php/kurawal
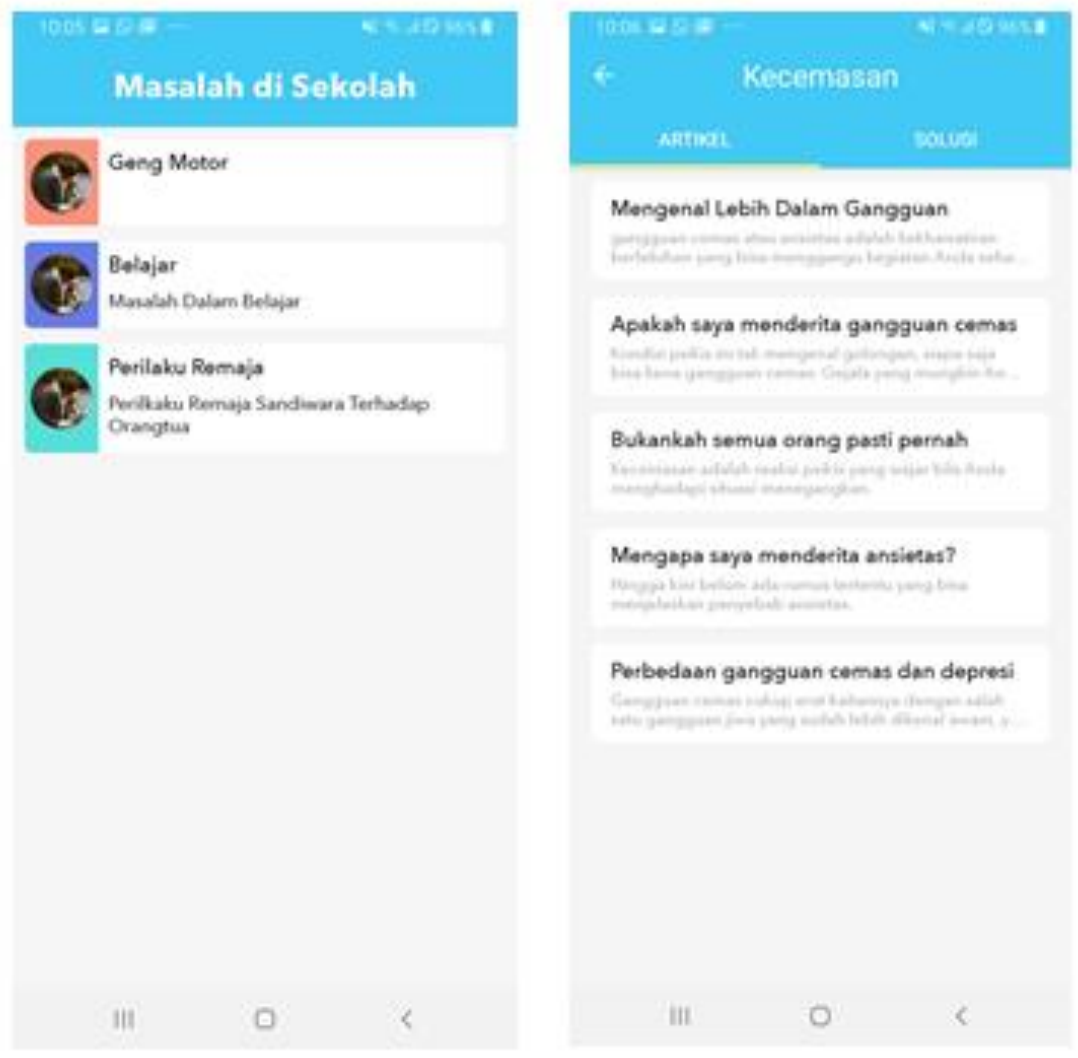

Gambar 2 pilihan sesuai dengan kebutuhan pribadi Menu

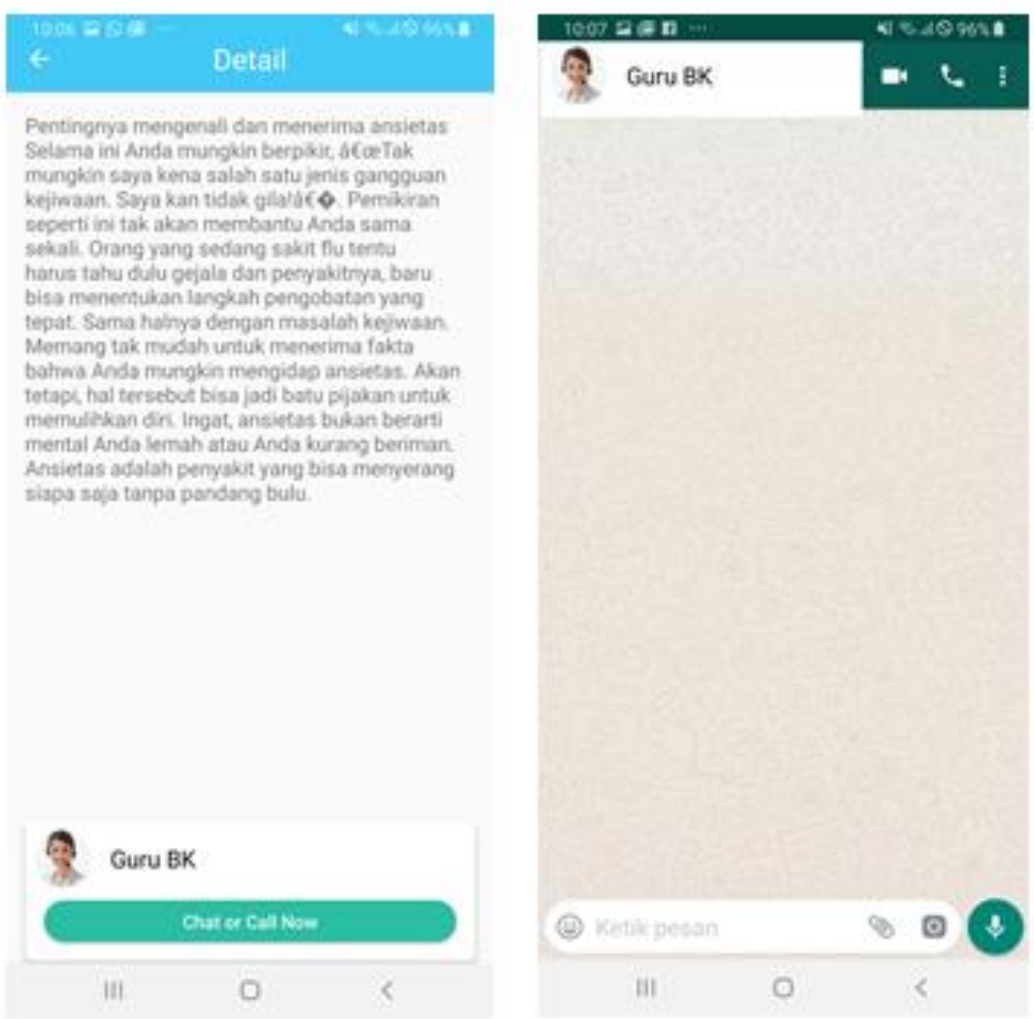

Gambar 3 Hasil konseling melalui whataspp (WA) 


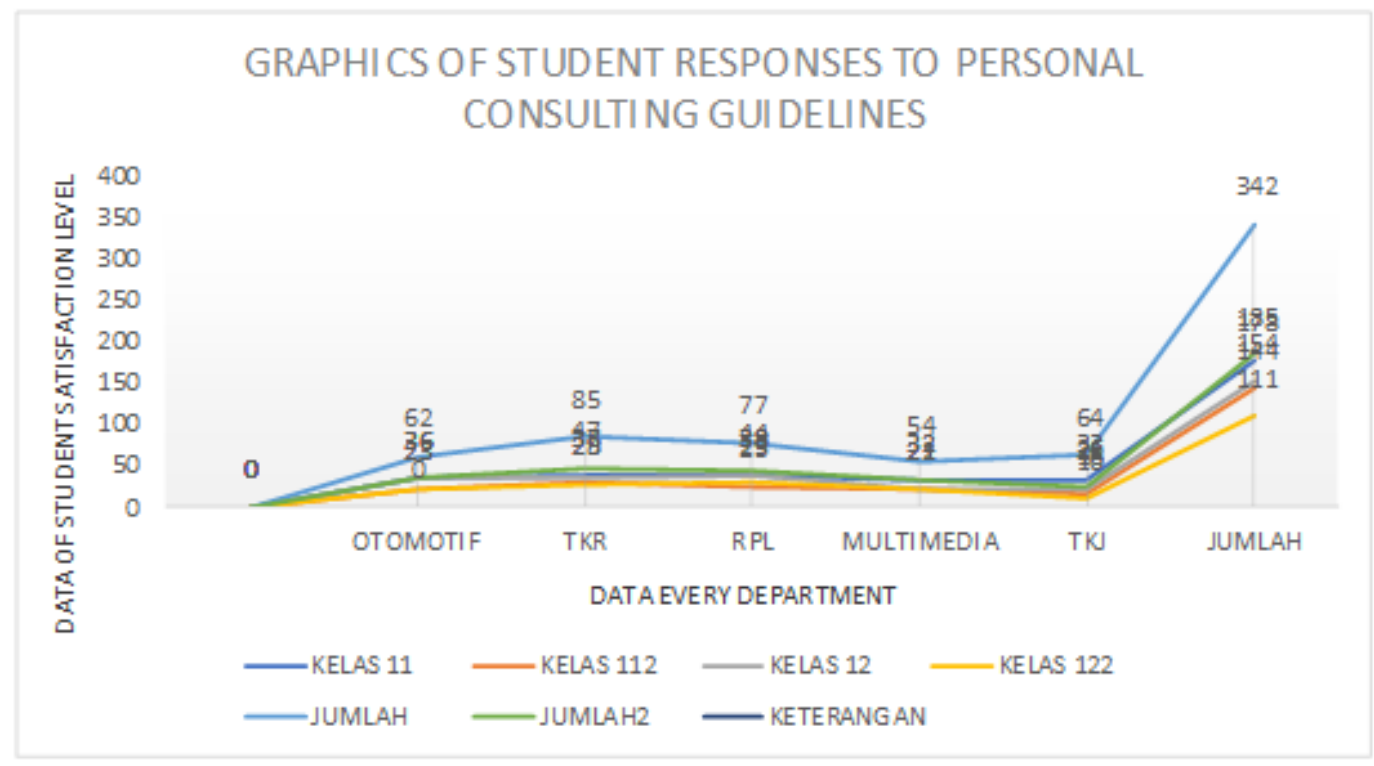

Gambar 4 Daftar Tanggapan Siswa terhadap Bimbingan Konseling Pribadi

5. Respons siswa terhadap kebutuhan layanan bimbingan konseling sebagaimana diuraikan dalam bentuk gambar grafik.

\section{HASIL DAN KESIMPULAN}

Berdasarkan penelitian yang telah dilakukan, ada beberapa hasil yang dapat diambil:

a) Peneliti telah dapat membangun sistem informasi konseling cyber yang sangat membantu sebagai pedoman guru dalam melakukan konseling kepada siswa.

b) Aplikasi yang dibuat dapat digunakan untuk mendukung guru dalam membuat keputusan dalam bimbingan konseling tentang situasi masalah siswa.

c) Sistem ini dibuat sangat efektif dan efisien untuk menyelesaikan masalah yang telah dihadapi oleh guru konseling guru, sehingga sangat membantu bagi siswa dan orang tua siswa.

d) Jelas bahwa pengoptimalisasi whatsapp adalah dasar dari komputasi mobile sangat penting dan sangat membantu bagi guru dalam melakukan konseling pada penyelesaian masalah siswa dan solusi mereka.

Dengan mengoptimalkan whatsapp berdasarkan komputasi mobile, para peneliti telah dapat membantu para guru dalam memecahkan masalah konseling siswa dengan akurasi $80 \%$. Diharapkan sistem ini dapat menggunakan aplikasi yang dibangun oleh para peneliti sehingga dapat membantu akurasi dan kecepatan dalam menyelesaikan masalah konseling siswa di setiap sekolah. 


\section{DAFAR PUSTAKA}

[1] Ali Ibrahim , 2013. Jurusan Sistem Informasi Universitas Sriwijaya, Inderalaya, Ogan Ilir, Sumatera Selatan, IMPLEMENTASI MOBILE COMPUTING DALAM PENGEMBANGAN SISTEM PAKAR UNTUK MENGUKUR TINGKAT KECEMASAN KARYAWAN, http://eprints.unsri.ac.id/ 5588/1/ MOBILE_ COMPUTING_SISTEM_PAKAR.pdf

[2] Andik Setyono, Erna Zuni Astuti, 2013, EKSPLORASI MOBILE COMPUTING UNTUK KOMUNIKASI DATA, Program Studi Teknik Informatika, Fakultas Ilmu Komputer, Universitas Dian Nuswantoro, Techno.COM, Vol. 12, No. 4, November 2013: 208-216

[3] Barak, A., \& Grohol, J. M. (2011). Current and future trends in Internet-supported mental health interventions. Journal of Technology in Human Services, 29, 155-196.

[4] Brahim Tanrikulu, World Conference on Educational Sciences 2009, Counselors-intraining students' attitudes towards online counseling, Department of Educational Sciences, Middle East Technical University, 06531, Ankara, Turkey, Procedia Social and Behavioral Sciences 1 (2009) 785-788, doi:10.1016/j.sbspro.2009.01.140

[5] C. Sgaras, M. T. Kechadi, and N. A. Le-Khac, "Forensics acquisition and analysis of instant messaging and VoIP applications," in Lecture Notes in Computer Science (including subseries Lecture Notes in Artificial Intelligence and Lecture Notes in Bioinformatics)vol. 8915, ed, 2015, pp. 188-199.

[6] Dmitriev, S., Kononov, A., Shiriaev, M., \& Malozemov, S. (2012). “Cloud computing for education in state technical University of Nizhny Novgorod". Proceedings of the 9th IFAC Symposium on Advances in Control Education (ACE '12) (pp. 418-420).

[7] Erick Kurniawan, 2015, PENERAPAN TEKNOLOGI CLOUD COMPUTING DI UNIVERSITAS , Studi Kasus: Fakultas Teknologi Informasi UKDW, Jurnal EKSIS Vol 08No01Mei 2015: halaman 29-36, https://media. neliti.com/media/publications/ 77964ID-penerapan-teknologi-cloud-computing-di-u.pdf

[8] Faye Mishna, Marion Bogo , Jami-Leigh Sawyer, Springer Science Business New York 2013, Cyber Counseling: Illuminating Benefits and Challenges, Factor-Inwentash Faculty of Social Work, University of Toronto, 246 Bloor Street West, Toronto, ON M5S 1V4, Canada,DOI 10.1007/s10615-013-0470-1

[9] Gupta, A., \& Agrawal, A. (2012).Internet counselling and psychological services. Social Science International, 28(1), 105-122.

[10] H. Bajaj and R. Jindal, "Thinking beyond WhatsApp," in 2015 International Conference on Computing for Sustainable Global Development, INDIACom, 2015, pp. 1443-1447.

[11] Haris Fadilah, 2013. Cloud Computing. [Online] (Updated 1 Juli 2013) URL: http://41215c41177. wordpress.com /2013/07/01/cloud-computing/[Diakses pada 3 November 2013. 
[12] Imam Mawardi,2015,

ICT(Information And Communication Technology)Sebagai Wahana Transformasi Pendidikan Dosen Pada Fakultas Agama Islam Universitas Muhammadiyah Magelang, http://download. portalgaruda.org/article.php?article=114626 \&val=5247

[13] Jerizal Petrus \& Hanung Sudibyo , 2017, Kajian Konseptual Layanan Cybercounseling

[14] Komputasi Mobil, Definisi Mobile Computing, Universitas Gunadarma. Jakarta

[15] Kuncoro, Mudrajad, 2001, Metode Kuantitatif (Teori dan Aplikasi untuk Bisnis dan Ekonomi), Unit Penerbit dan Percetakan AMP YKPN, Yogyakarta

[16] Lennon, R. G. (2012). "Bring your own device (BYOD) with cloud 4 education". Proceedings of the 2012 3rd Annual Conference on Systems, Programming, Languages and Applications:Software for Humanity (SPLASH '12) (pp. 171-180)

[17] M. Seufert, T. Hoßfeld, A. Schwind, V. Burger and P. Tran-Gia, "Group-based communication in WhatsApp," 2016 IFIP Networking Conference (IFIP Networking) and Workshops,Vienna, Austria, 2016, pp. 536-541.

[18] Mathew, A.B., Madhu Kumar, S.D. Analysis of data management and query handling in social networks using NoSQL databases. International Conference on Advances in Computing, Communications and Informatics (ICACCI), 2015, pp. 800-806

[19] N. Statt. WhatsApp has grown to 1 billion users, 2016.

Available: http://www.theverge.com/2016/2/1/10889534/whats-app-1-billion-usersfacebook-mark-zuckerberg

[20] M. nazir, 1988, Metode Penelitian, (Jakarta : ghalia Indonesia, 1988), hlm. 72-73

[21] Safaat H, Nazruddin. (2011). Pemrograman Aplikasi Mobile Smartphone dan Tablet Berbasis Android.Bandung: Informatika.

[22] Sariyun Naja Anwar, Isworo Nugroho , Endang Lestariningsih, 2015,Perancangan Dan Implementasi Aplikasi Mobile Semarang Guidance Pada Android Fakultas Teknologi Informasi, Universitas Stikubank Semarang, Jurnal Teknologi Informasi DINAMIK Volume 20, No.1, Juli 2015 : 148-158 ISSN : 0854-9524

[23] Sibel Dincyurek, Gulen Uygarer. (2012). Conduct of Psychological Counseling and Guidance Services Over The Internet: Converging Communications. TOJET: The Turkish Online Journal of Educational Technology -July 2012. Volume 11 Issue 3. http://www.tojet.net/ articles/v11i3/1138.pdf

[24] Siti Aisyah, Muhammad Asrori, Yuline. Program Studi Ilmu Pendidikan Bimbingan dan Konseling FKIP Untan Pontianak, PENGARUH PEMANFAATAN WHATSAPP TERHADAP INTERAKSI ANAK DAN ORANG TUA PESERTA DIDIK SMPN 10 
URL : https://jurnal.machung.ac.id/index.php/kurawal

PONTIANAK, http://jurnal.untan.ac.id /index.php/jpdpb/ article/viewFile/ 25638/75676576733

[25] Statsky, William P. (2016). Introduction To Paralegalism Prespektive, Problems And Skills. United states of America: Cengage Learning.

[26] Sugiyono. 2005.: 21, Metode Penelitian Administrasi. Bandung : Alfabeta

[27] Tole Sutikno, 2016, WhatsApp, Viber and Telegram: which is the Best for Instant Messaging? Department of Electrical Engineering, Faculty of Industrial Technology, Universitas Ahmad Dahlan International Journal of Electrical and Computer Engineering (IJECE) ,Vol. 6, No. 3, June 2016, pp. 909 914 ,ISSN: 2088-8708, DOI: 10.11591/ijece.v6i3.10271

[28] Triyono,2018, Universitas Negeri Malang, MEREKA -REKA STRATEGI BIMBINGAN DAN KONSELING DALAM ERA DISRUPSI/REVOLUSI INDUSTRI 4.0 BAGI GENERASI Z, PROSIDING SEMINAR NASIONAL, Strategi Pelayanan Bimbingan dan Konseling di Era DisrupsiSemarang, 21 Juli 2018, ISBN 9786021180389, Volume 6 Number1 2017, pp. 6-12 ISSN: Print 1412-9760 -Online 2541-5948 DOI: 10.24036/02017616724-0-00, http://ejournal.unp.ac.id/index.php/konselor 